\title{
THE DISTRIBUTION OF BATIK INDUSTRY TOWARD SOCIETY INCOME IN KENEP VILLAGE SUKOHARJO SUB DISTRICT SUKOHARJO DISTRICT 2018
}

\author{
Try Solekah Dewi ${ }^{1}$, Agus Sudargono ${ }^{2}$, Pranichayudha Rohsulina ${ }^{3}$ \\ 1,2,3 Geography Education Study Program, Sukoharjo Veteran Bangun \\ Nusantara University \\ Email : trysolekah@gmail.com
}

\begin{abstract}
This study aims to know : 1) the influence of Batik industry on society income in Kenep Village, 2) the distribution of Batik Industry in Kenep Village. This study used qualitative descriptive method and sampling population for the sampling method. The data collection method in this research is through field observation, interview, and questionairre documentation while the data analyse method used frequency table, cross table analysis, map analysis, and qualitative descriptive analysis. This study found that the majority of Batik Industry owners was dominated by woman in the age range 15-64 years old and mostly they have already married. Besides, mostly of them were graduated from Junior High School. Batik Kedunggudel is an inheritance industry that produces written, stamp, and printing Batik. The market range of Batik Kedunggudel in Kenep Village includes Java, Sulawesi, and Kalimantan Island. The marketing method of Batik Kedunggudel is : using online application and shipping service. The majority of labors of this industry is dominated by man. This industry has capital business around $<R$ p.51.000.000 with average income around $<R$. 10.000.000 each month, while the labor obtain Rp.1.500.000 as their salary per month, not including wholesale salary.
\end{abstract}

Keywords : Batik Industry, distribution, income

\section{A. INTRODUCTION}

The government is trying to develop other sectors to help the agricultural sector in terms of increasing income and employment. The sector that is expected to increase income and absorb labor is the industrial sector. The industrial sector always gets attention in the implementation of development in Indonesia. This sector has become the focus of economic development since it is regarded as the driving force of other economic 
sector's growth to boost the national economic condition. Currently, industrial sector is one of the main components in national economic development.

Industry is an economic activity that processes raw materials, raw materials, semi-finished goods, and / or finished goods, becoming goods of higher value for its users. In fact, the development of small scale-based industry in Indonesia has lost its momentum and its influence to support the success of economic development programs initiated by the government (Hinelo, in Anak Agung: 566).

The writer is interested in batik industry in Kenep Village that has many prospects to support tourism village program. This year, the initial stages of structuring are expected to be completed to improve the existing potential. These potentials include culinary businessman, batik craftsmen, and natural locations on the bank of Bengawan Solo River. This statement was conveyed by Kenep village head, Sugiyatno. The concept of going to the Eco Cultural Tourism Village from Kenep Village is still being discussed at the DPU Office Hall in Sukoharjo.

The industry of written Batik in Kenep Village is greatly interested by people inside and outside Kenep Village, for example the business of Batik Sendang Mulyo that was established in 2003. This industry utilizes canting as traditional technique to drawing batik and uses sponge tied with stick to coloring them. The hand skill of Batik artisan can result a magnificent work that has high economic value. In a month, this industry can produce 500 pieces of batik with an income around Rp. 10 million / month. The selling price of Batik fabric is approximately Rp. 150.000/2 meter for written combination batik while the selling price for clothing Batik is around Rp.200.000. The marketing range of Batik Sedang Mulyo has reached area around solo, jogja, salatiga, jakarta. (http: // kelurahankenep: 2013). 


\section{B. RESEARCH METHOD}

This is qualitative study in which the activites are taken to answer the qestion of how and why. The method used is descriptive method by describing research subjects based on current facts and circumstances. Descriptive methods are more directed at disclosing a problem or situation and revealing the facts, although sometimes interpretations or analyzes are given. The results of this study are focused on providing an overview of the actual condition of the observed object (Tika in Nugraheni 2015: 43). This descriptive method provides a sistematic overview about the socialeconomic condition of Batik craftsmen and the production factor of Batik Industry in Venep Village, Sukoharjo Sub District, Sukoharjo District.

The population used in this study are batik artisans and entrepreneurs in Kenep Village. Data related to the number of Batik owners will be obtained by using absolute points in the field with GPS (Plotting area), while the total population will be used to determine the distribution of batik industry. This research used Simple Random Sampling and Simple Population that was taken randomly regardless the strata in population. All samples will be taken if the number of subject is less then 100 while if the subject is more than 100 then the sample will be taken between $10-15 \%$ or $20-25 \%$ from Batik artisan and businesseman population. This technique is used to know the distribution of Batik craftsmen in Kenep Village. The population data in this research is in the form of absolute location of batik craftsmen and entrepreneurs through GPS and field observations. This research was conducted in May 2018. The number of respondent in this study is 50 participants for Batik craftsmen and 5 participants for Batik enterpreneur. The result of this study will be presented in table or diagram form, including other variables such as age, gender, marital status of respondents. 
An analysis will be done to know socio-economic condition of society as well as the production factor of Batik industry through one way and frequency table analysis. The frequency table is used to depict the research sample and to categorize data. Spatial analysis using map is used to know the distribution of Batik Industry through GIS technique that consists of the process of inputting data from absolute locations and results map of batik industry distribution as the output.

Validation is used to find the stability and correctness of collected data by using triangulation method. This method is done by comparing the results of field observations and interviews, then it can result high quality and validity of analysis. Validation test of this study is conducted through field observation to prove whether each variable in the research object is in accordance with reality or not. The researcher also conducted interviews with related parties to strengthen the description of the observations.

\section{RESULT AND DISCUSSION}

\section{Respondent Data}

a. Respondent Age

From the data obtained, it can be seen that the majority of respondents, both entrepreneurs and batik artisans who work in the Kenep Sub-District of Sukoharjo Subdistrict, are in productive age, namely 34 people (97.14\%) are between 19-64 years while the rest are unproductive which is only 1 person or $2.86 \%$ with ages between 65 years.

\section{b. Gender}

The respondents are dominated by female about 23 people $(65.72 \%)$. It is caused by the work of making Batik needs thoroughness and patience as becomes the character of woman. Meanwhile, the role of men in this industry is in the process of making printed batik and other activities that use much energy such as coloring and removing malam (residual ink) of batik fabric. 
c. Respondent's Residence

The majority of respondents live in Kedunggudel Hamlet, Kenep SubDistrict while others live in Dukuh Soko, Dukuh Sabunan, and Dukuh Bangkekan. The total population in study area is 425 people with 235 and 190 are female and male respectively.

d. Education Level

The majority of respondents is graduated from Junior High School / equivalent with 13 people or $37.14 \%$ from total population. For Industry owner, the details are 1 person graduated from Senior High School, 1 person graduated from Junior High School, and 4 persons graduated from university. While for industry craftsmen, the details are 8 persons graduated from elementary school, 12 persons graduated from Junior High School, and 9 persons graduated from Senior High School with 29 people as total population.

e. Marriage Status

From observation, it can be seen that 30 people $(85.71 \%)$ have been marriage while 5 respondents (14.29\%) are unmarried.

\section{The Influence of Batik Industry on Batik Enterpreneur's Income}

a. Job Status of Entrepreneurs

Table 1. The job status of Batik Kedunggudel Industry Owner of Kenep Village Sukoharjo Sub District 2018

\begin{tabular}{rrccc}
\hline \multirow{2}{*}{ No } & \multirow{2}{*}{ Job } & \multicolumn{2}{c}{ Total } \\
\cline { 4 - 5 } & & person & $\%$ \\
\hline 1 & Main Job & 4 & 80,00 \\
2 & Side Job & 1 & 20,00 \\
\hline & Total & 5 & 100 \\
\hline
\end{tabular}

Source : Primary Data 2018

From above table, it can be seen that there are 4 people $(80 \%)$ who run Batik Industry as their main jobs while 1 person (20\%) runs it only as side 
job. Therefore, it can be conclude that most society in study area makes Batik Industry as their main jobs instead of side job.

\section{b. First Capital}

Table 2. Initial Capital of Batik Kedunggudel Industry in Kenep Village Sukoharjo Sub District 2018

\begin{tabular}{clcc}
\hline \multirow{2}{*}{ No } & \multicolumn{2}{c}{ Initial Capital } & \multicolumn{2}{c}{ Total } \\
\cline { 3 - 4 } & & Person & $\%$ \\
\hline 1 & Rp.1.000.000 - Rp.10.000.000 & 3 & 60,00 \\
2 & Rp.11.000.000 - Rp.20.000.000 & 1 & 20,00 \\
3 & $>$ Rp.20.000.000 & 1 & 20,00 \\
\hline & Total & 5 & 100 \\
\hline
\end{tabular}

Sumber : Primary Data 2018

Based on above table, it can be seen that the range of initial modal to run Batik Industry is between Rp. 1.000 .000 - Rp. 10.000.000 with details 3 persons (60\%), with Rp.1.000.000 - Rp.10.000.000, 1 person (20\%) with Rp.11.000.000 - Rp.20.000.000 and 1 person (20\%) with capital more than Rp.20.000.000.

c. Production Cost

Table 3. Production Cost of Batik Kedunggudel Industry in Kenep Village Sukoharjo Sub District in 2018

\begin{tabular}{|c|c|c|c|}
\hline \multirow{2}{*}{ No } & \multirow{2}{*}{ Production Cost } & \multicolumn{2}{|c|}{ Total } \\
\hline & & Person & $\%$ \\
\hline 1 & Rp.1.000.000 - Rp.50.000.000 & 3 & 60,00 \\
\hline 2 & $\begin{array}{l}\text { Rp.51.000.000 - } \\
\text { Rp.100.000.000 }\end{array}$ & 2 & 40,00 \\
\hline 3 & $>$ Rp. 100.000 .000 & - & - \\
\hline & Total & 5 & 100 \\
\hline
\end{tabular}

From the table, it can be known that Industry owner has to discharge the production cost including purchasing raw material, work's salary, production and marketing process about Rp. 1000.000 - Rp.50.000.000 
monthly for 3 respondents while Rp.51.000.000- Rp.100.000.000 for the rest.

\section{d. Salary Income}

Table 4. The Owner's Salary of Batik Kedunggudel Industry in Kenep Village Sukoharjo Sub District in 2018

\begin{tabular}{clcc}
\hline \multirow{2}{*}{ No } & \multicolumn{1}{c}{ Income } & \multicolumn{2}{c}{ Total } \\
\cline { 3 - 4 } & & Person & $\%$ \\
\hline 1 & Rp.1.000.000 - Rp.5.000.000 & 1 & 20,00 \\
2 & Rp.6.000.000 - Rp.10.000.000 & 4 & 80,00 \\
3 & $>$ Rp.10.000.000 & - & - \\
\hline & Total & 5 & 100
\end{tabular}

Source : Primary Data 2018

Averagely, the net income of Batik Industry owners is relatively high with more than Rp.1.500.000 per 2 months. Compared to Minimum Salary Standard of Sukoharjo Regency which is around Rp. 1.500.000, it can be said the income of Industry owner exceeds the average standard. It shows that the majority of respondents have achieved their success to fulfill their family needs.

e. Marketing

Table 5. The marketing of Batik Kedunggudel products in Kenep Village Sukoharjo Sub District in 2018

\begin{tabular}{lccc}
\hline \multirow{2}{*}{ Marketing Method } & \multicolumn{2}{c}{ Total } \\
\cline { 2 - 4 } & & Person & $\%$ \\
\hline Direct & 2 & 40,00 \\
Indirect & 3 & 60,00 \\
\hline & Total & 5 & 100 \\
\hline
\end{tabular}

The majority of Batik enterpreneurs sell their products in indirect method by using other service (broker) around 3 people (60\%) while the rest population ( 2 persons $)$ has directly marketed their products. The scope of 
marketing includes Java areas : Solo, Jogjakarta, Jakarta, and outside Java : Sulawesi and Kalimantan.

\section{The Influence of Batik Industry on Batik Artisan's Income}

a. Craftsmen Work Status

Table 6. The Job Status of Batik Keduggudel workers in Kenep Village Sukoharjo Sub District in 2018

\begin{tabular}{cccc}
\hline \multirow{2}{*}{ No } & \multirow{2}{*}{ Job Status } & \multicolumn{2}{c}{ Total } \\
\cline { 3 - 4 } & & Person & $\%$ \\
\hline 1 & Main Job & 29 & 96,67 \\
2 & Side Job & 1 & 3,33 \\
\hline & Total & 30 & 100 \\
\hline
\end{tabular}

Source : Primary Data 2018

From table, it can be seen that there are 29 people $(96,67 \%)$ who put Batik industry as their main jobs while only 1 person $(3,33 \%)$ makes it as side job. Therefore, it can be concluded that mostly the Batik craftsmen place this industry as main job instead of side job.

b. Working duration

It was observed that there are 15 respondents (50\%) ho have working duration around 1-5 years while 15 respondents (50\%) have worked for 610 years.

c. Worker's Salary

Table 7. The Income of Batik Kedunggudel's Artisan in Kenep Village in 2018

\begin{tabular}{cccc}
\hline \multirow{2}{*}{ No } & \multirow{2}{*}{ Income } & \multicolumn{2}{c}{ Total } \\
\cline { 3 - 4 } & & Person & $\%$ \\
\hline 1 & $<1.500 .000$ & 7 & 23,33 \\
2 & 1.500 .000 & 14 & 46,67 \\
3 & $>1.500 .000$ & 9 & 30,00 \\
\hline & Total & 30 & 100 \\
\hline
\end{tabular}

Source : Primary Data 2018

The above table shows that the average salary of Batik Kedunggudel's artisan is about Rp.1.500.000 per month. It has been sufficient compared 
to Minimum Salary Standard (UMR) of Sukoharjo Regency which is also around Rp.1.500.000. It proves that mostly respondents are able to reach their success and to fulfill their family needs.

\section{The Distribution of Batik Kedunggudel}

This study used spatial analysis through map to analyze the distribution of Batik Industry in the study area. Map is used as media to display the location of Batik Industry that is symbolized by points. From these points, then it will be known the distribution of Batik Industry. The determination on the amount of points is matched with the population number of Batik Industry in the study area.

Table 8. The Distribution of Batik Industry in Kenep Village Sukoharjo Sub District in 2018

\begin{tabular}{|c|c|c|c|c|}
\hline \multirow[b]{2}{*}{ No } & \multirow[b]{2}{*}{ Industry Owner } & \multicolumn{3}{|c|}{ Lokasi } \\
\hline & & $\begin{array}{l}\text { Longitude } \\
\text { (X) }\end{array}$ & $\begin{array}{l}\text { Latitude } \\
\text { (Y) }\end{array}$ & Village \\
\hline 1 & $\begin{array}{l}\text { Ibu Al Anis Sehatiningsih } \\
\text { (Batik Al Anis) }\end{array}$ & $110^{\circ} 48^{\prime} 26.568^{\prime \prime}$ & $-7^{\circ} 42^{\prime} 39.82^{\prime \prime}$ & $\begin{array}{l}\text { Kedunggudel, } \\
\text { Rt.01/01 Kenep }\end{array}$ \\
\hline 2 & $\begin{array}{l}\text { Bapak Agus Samiyono } \\
\text { (Batik Kedunggudel) }\end{array}$ & $110^{\circ} 48^{\prime} 26.946^{\prime \prime}$ & -742'30.114" & $\begin{array}{l}\text { Kedunggudel, } \\
\text { Rt.03/01 Kenep }\end{array}$ \\
\hline 3 & $\begin{array}{l}\text { Bapak Darmaji, S.T } \\
\text { (Batik Sendang Mulyo) }\end{array}$ & $110^{\circ} 48^{\prime} 34.779^{\prime \prime}$ & $-7^{\circ} 42^{\prime} 12.513^{\prime \prime}$ & $\begin{array}{l}\text { Kedunggudel, } \\
\text { Rt.05/01 Kenep }\end{array}$ \\
\hline 4 & $\begin{array}{l}\text { Ibu Rina Wijayaten, S.T, } \\
\text { S.Pd } \\
\text { (Batik Melathi Wijaya) }\end{array}$ & $110^{\circ} 48^{\prime} 25.819^{\prime \prime}$ & $-7^{\circ} 42^{\prime} 40.474^{\prime \prime}$ & $\begin{array}{l}\text { Kedunggudel, } \\
\text { Rt.01/01 Kenep }\end{array}$ \\
\hline 5 & $\begin{array}{l}\text { Bapak Ario Sri Wahono, } \\
\text { S.Sn dan bapak Haryanto } \\
\text { (Batik Bogamas) }\end{array}$ & $110^{\circ} 48^{\prime} 27.284^{\prime \prime}$ & $-7^{\circ} 42^{\prime} 36.018^{\prime \prime}$ & $\begin{array}{l}\text { Kedunggudel, } \\
\text { Rt.02/01 Kenep }\end{array}$ \\
\hline
\end{tabular}

Source : Primary Data 2018

Dominantly, Batik Industry in Kenep Village is inherited from previous generation to next generation and it is counted around 5 industries within the study area. This industry has become the primary jobs of surrounding 
people. Among other hamlets in Kenep Village, Batik products from Kedunggudel Hamlet attracts more consumers to come and make it as the centre of Batik in Kenep Village.

The influence of Batik Kedunggudel Industry to society income of Batik enterpreneurs and artisans :

a. The economic condition of Batik enterpreneur

This condition includes job status, initial capital, production cost, salary level, and marketing. The majority of Batik enterpreneurs put Batik industry as their main jobs (80\%) while the rest (20\%) only make it as side job. The initial capital of Batik owner is around Rp.1.000.000Rp.10.000.000 mostly (60\%) and other owners is around Rp.10.000.000Rp.50.000.000 monthly. The average income of $80 \%$ owners (4 persons) from this industry is around Rp.6.000.000-10.000.000 per month. In addition, $60 \%$ of Batik products is marketed using indirect marketing method (through broker or shiping service). Moreover, to provide marketing for big party (such as uniform product), the owners will cooperate with third party such as convection industry to fulfill the orders so it creates mutual relationship between Batik Industry with other industries in Kenep village Sukoharjo Sub District Sukoharjo District.

\section{b. The economic condition of Batik Artisan}

This condition includes job status, job type, job duration, and income level of Batik craftsmen. It can be observed that commonly Batik artisan put this indusrty as their main jobs which is around $96,67 \%$ while the rest $(3,33 \%)$ make it as side job. It is proven that this industry is able to reduce the number of unemployment in Kenep Village.

Based on the type of job, $40 \%$ of Batik craftsmen is responsible to design Batik and $56,67 \%$ is responsible to process Batik that has been ready to sell. The work duration of artisan is around 1-5 years for 15 people (50\%) 
and 6-10 years for the rest (15 persons). For those who work to make Batik design, it can be done in their own home and then it can be sent to industry owner once it is finished. Lastly, the income of 14 labors $(46,67 \%)$ is comparable to the average of minimum salary standard (UMK) of Sukoharjo regency.

Geographic Information System can be used to display the distribution map of Batik Industry in Kenep Village, starting from putting the locational points from ground survey to analysing data to create a distribution map of Batik Industry in observed area. The determination of the number of points is based on the total population of Batik Industry in Kenep Village. The total population of Batik Industry in Kenep village is 5 industries that is spread over Kedunggudel Hamlet, and later it is commonly called with Batik Kedunggudel.

\section{CONCLUSION AND RECOMMENDATION}

The influence of Batik Kedunggudel Industry in Kenep Village toward enterpreneur and artisan society is : the majority of Batik Kedunggudel Industry is an inheritance business while others started by their own; the raw material to process batik is obtained from the town, particularly from Klewer Market; the marketing range of Batik products includes Java such as Solo and Jogjakarta and other islands such as Sulawesi; the capital business is around Rp.1.000.000 - Rp.10.000.000; the income of enterpreneur exceeds minimum salary standard (UMK) while for craftsmen is equivalent to UMK which is around Rp. 1.500 .000 ; the presence of Batik Kedunggudel industry is success to reduce the number of unemployment in Kenep Village; The distribution of batik industry in Kenep village is centralized at Kedunggudel Hamlet which has 5 enterpreneurs who sell different kind of Batik products such as written batik, stamped batik, and printed batik. 
The government should get involved in the promotion of Batik Kedunggudel products to increase productivity of this industry. Also, the government should pay more attention to Batik Industry by providing trainings to its agents so this industry so it can be more developed. It also needs to stimulate young generation to learn how to make Batik to keep this industry sustainable. For Batik Kedunggudel owners, hopefully their business can be preserved in order to open job vacancies in village area. It also need to expand the marketing area as well as to improve batik design or model.

\section{E. REFERENCE}

Anak A.R.W dan Ida B.D. 2015. Pengaruh Modal, Tenaga Kerja, Dan Lama Usaha Terhadap Pendapatan Pengrajin Industri Kerajinan Anyaman di Desa Bona Kecamatan Blahbatuh Kabupaten Gianyar . E-jurnal EP Unud. (https://ojs.unud.ac.id/index.php/eep/article/view/28386/17876).

Diakses pada 24 November 2017.

Abdul Majid. 2008. Pengertian, Konsep, Definisi Pemasaran Dan Manajemen Pemasaran. http://majidbsz. wordpress.com /2008/06/30/ pengertian konsep-definisi-pemasaran/. Diakses pada tanggal 28 November 2018.

Asti M dan Ambar B.A. 2011. Batik Warisan Adiluhung Nusantara. Yogyakarta: G-media

Banowati, Eva. 2014. Geografi Indonesia. Yogyakarta:Ombak.

http://kelurahankenep.blogspot.co.id/p/blog-page_3: 2013 (Diakses 24 November 2017)

Indarto. 2013. Sistem Informasi Geografis. Yogyakarta: Graha Ilmu.

Liesnoor Setyawati, Dewi.dkk. 2014. Kartografi Dasar. Yogyakarta : Ombak.

Mantra, Ida Bagoes. 2003. Demografi Umum. Jakarta: Pustaka Pelajar.

Moleong,Lexy. 2014. Metode Penelitian Kuantitatif Kualitatif. Bandung :PT. Remaja Rosdakarya

Monografi Penduduk Desa Kenep Tahun 2017-2018.

Murti, Eri. 2009. Studi Industri Genteng Di Desa Demakan Kecamatan Mojolaban Kabupaten Sukoharjo Tahun 2007. Skripsi Pendidikan Geografi: Universitas Sebelas Maret Surakarta.

Nugraheni, Sulistyowati. 2015. Karakteristik Dan Pola Persebaran Pedagang Hidangan Istimewa Kampung (HIK) Di Kecamatan Sukoharjo Kabupaten Sukoharjo Tahun 2015. Skripsi Pendidikan Geografi: Universitas Veteran Bangun Nusantara Sukoharjo. 
Perdana Prasetya, Sukma. 2016. Sumber Penunjang PLPG 2016 Mata Pelajaran Paket Keahlian Ilmu Pengetahuan Sosial. Kemendikbud. (Http://Fkip.Unri.Acid/WpContent/Uploads/2016/09/Bab-Iv-Konsepsi-Produksi-DistribusiDan-Konsumsi-Dalam-Pemenuhan-Kebutuhan-Penduduk.Pdf.)

Diakses Pada 10 Januari 2018.

Permatasari, Sintia. 2017. Kondisi Sosial Ekonomi Masyarakat Pengrajin Gitar di Desa Mancasan Kecamatan Baki Kabupaten Sukoharjo Tahun 2017. Skripsi Pendidikan Geografi: Universitas Veteran Bangun Nusantara Sukoharjo.

Setiawan, Joko. 2012. Analisis Beberapa Faktor Yang Mempengaruhi Tingkat Pendapatan Industri Kecil Sepatu Kulit di Kabupaten Magetan. Jurnal Akmenbis. Vol. 1, No 01. (https://gicibusinessschool.ac.id/wpcontent/uploads/jurnal/Jurnal-AKMENBIS-02.pdf )Diakses pada 25 November 2017.

Sugiyono. 2014. Metode Penelitian Kuantitatif Kualitatif Dan R\&D. Bandung: Alfabeta.

Suharyono dan Moch. Amin. 2013. Pengantar Filsafat Geografi. Yogyakarta : Ombak

Susanti, Nelly. 2013. Dampak Keberadaan Kampus Unnes Terhadap Kondisi Ekonomi Dan Pendidikanpenduduk Kelurahan Sekaran Kecamatan Gunungpati Kota Semarang (Tahun 2006-2010. Skripsi. Universitas Negeri Semarang). (Lib.Unnes.Ac.Id/19931/1/3201408011.Pdf). Diakses 27 November 2017.

Wibowo, Junanto. 2014. Pola Persebaran Sentra Industri di Kota Pekalongan Berbasis Sistem Informasi Geografis. Skripsi: Universitas Negeri Semarang. (Lib.Unnes.Ac.Id/19931/1/3201408011.Pdf) . Diakses pada 26 November 2017.

Widoyoko,Eko Putro.2015. Teknik Penyusunan Instrumen Penelitian. Yogyakarta : Pustaka Pelajar 